\title{
BLOOM OF Noctiluca scintillans (MACARTNEY) KOFOID \& SWEZY (DINOPHYCEAE) IN SOUTHERN BRAZIL
}

\author{
Luciana de Souza Cardoso*
}

Universidade Federal Rural do Rio Grande do Sul

Instituto de Biociências, Departamento de Botânica

(Av. Bento Gonçalves, 9500, Prédio 43433, 91501-970 Porto Alegre, RS, Brasil)

*Corresponding author: luciana.cardoso@ufrgs.br

Descriptors: Bloom, HAB (Harmful Algal Bloom), Dinoflagellates, Subtropical.

Descritores: Floração, FAN (Floração de Alga Nociva), Dinoflagelados, Subtropical.

The dinoflagellate Noctiluca scintillans (Macartney) Kofoid \& Swezy, commonly called sea sparkle, can aggregate into a bloom, and sometimes produces substances that are potentially toxic to marine life. Noctiluca scintillans is a large (up to 1200 $\mu \mathrm{m})$, oblong, luminescent heterotrophic dinoflagellate, and is frequently associated with bloom events (ELBRACHTER; QI, 1998). The species is considered non-toxic, but is sometimes responsible for the mortality of fish and benthic fauna, associated with anoxia. More recently, it has been reported that $N$. scintillans may act as a vector of phycotoxins to higher trophic levels, by feeding on toxigenic microalgae (ESCALERA et al., 2007).

Noctiluca scintillans is widely distributed in temperate to tropical regions, where it commonly causes blooms (SRIWOON et al., 2008). The mechanism of bloom formation of $N$. scintillans has been examined in many parts of the world, e.g., in the German Bight (UHLIG; SAHLING, 1990), Dapeng Bay, South China Sea (HUANG; QI, 1997; WANG et al., 2008), Minnie Bay, Andaman Islands (EASHWAR et al., 2001; DHARANI et al., 2004), Sagami Bay, Japan (MIYAGUCHI et al., 2006), Thailand (SRIWOON et al., 2008), Gulf of Mannar, India (GOPAKUMAR et al., 2009), Red Sea off Saudi Arabia (MOHAMED; MESAAD, 2007), northern Adriatic Sea (UMANI et al., 2004), and several parts of the Australian coast (AJANI et al., 2001, MURRAY; SUTHERS, 1999, DELA-CRUZ et al., 2002).

Blooms by $N$. scintillans appear either pinkish-red or greenish. The former coloration has been reported in various temperate and subtropical waters, but the latter occurs only in tropical waters of the western Pacific and Indian oceans (ELBRACHTER; QI, 1998, SAITO; FURUYA, 2006). The majority of blooms are harmless water discolorations, predominantly caused by $N$. scintillans (AJANI et al., 2001). Hereafter, N. scintillans that lacks the symbiont is referred to as red Noctiluca (SRIWOON et al., 2008).

On the coast of the state of Rio Grande do Sul (RS), most blooms are formed by diatoms
(Asterionellopsis glacialis). However, high concentrations of dinoflagellates are occasionally found, associated with low wave energy and high light intensity (ODEBRECHT et al., 1995). On the southern coast of Brazil, four mortality events have been recorded for the benthic fauna, associated with the presence of potentially toxic dinoflagellates (MACHADO, 1979; ROSA; BUSELATO, 1981; GARCIA et al., 1994, ODEBRECHT et al., 1995, MENDEZ, 1995). In this region, dinoflagellate blooms are irregular and seem to be more a response to the vagaries of unpredictable shifts in climatic factors, than to a deterministic mechanism. Nocturnal bioluminescence of Noctiluca scintillans was observed in northern RS in summer 2005, but was recorded only by a local newspaper (Zero Hora).

The northern coast of Rio Grande do Sul extends for $120 \mathrm{~km}$ from Torres Beach at the border with the state of Santa Catarina, southward to Pinhal Beach. During three days in December 2008, a red color on the sea was visible from the beach $[1]$. On the first day (17 December), the bloom was visible at Capão da Canoa Beach (nearly $70 \mathrm{~km}$ from Torres Beach) and moved southward to Cidreira and Pinhal beaches by the third day (19 December), after which it vanished. The present report describes the first recorded reddish bloom of Noctiluca scintillans on the northern coast of Rio Grande do Sul, Brazil.

The area off the RS continental margin is influenced by several water masses, including the Tropical Water (TW) of the Brazil Current; the South Atlantic Central Water (SACW), also called Subtropical Water (STW); and the coastal branch of the Falklands Current, which transports Sub-Antarctic Water (SAW). The thermohaline properties of water on the continental shelf vary as a result of the volume of fresh water discharged by the plume of the Plate River (RPP) and the Patos Lagoon, and the degree of influence of the TW and SAW. More locally, four water masses influence the northern coast: Subtropical Water of the continental shelf (STWP), Sub-Antarctic Water of the continental shelf (SAWP), Tropical Water (TW), and the South Atlantic Central Water (SACW). Only the TW $\left(\geq 18.5^{\circ} \mathrm{C} ; \geq 36 \%\right.$ ) and SACW 
$\left(\leq 18.5^{\circ} \mathrm{C} ; \geq 35.3 \%\right.$ o $)$ show temperature and salinity patterns independent of the seasons (MÖLLER et al., 2008). The discharge from Tramandaí Lagoon influences, to different degrees, the thermohaline properties of the water on the northern coast, mainly during the winter rains, but to a lesser degree than the larger Patos Lagoon and the Plate River.

During the morning of day 2 (December 18 2008) of the bloom, surface-water samples were collected from a PETROBRAS vessel, $800 \mathrm{~m}$ from Tramandaí Beach. The samples were collected following standard sampling procedure (APHA, 1995), using Van Dorn bottles (two, 1-L samples for quantitative analysis) and a plankton net with $63 \mu \mathrm{m}$ mesh (one 1-L sample for qualitative analysis) in the same area of the bloom. The temperature was taken simultaneously, with a manual thermometer.

Noctiluca cell numbers were estimated from the mean counts in $1-\mathrm{mL}$ and $5-\mathrm{mL}$ water samples; cells were counted in the entire volume of a SedgwickRafter chamber, using a Zeiss inverted microscope. The density was calculated in cells per liter (APHA, 1995).

A single species of $N$. scintillans formed a broad streak about $3 \mathrm{~m}$ wide and $50 \mathrm{~m}$ long, with a thick soup-like consistency. During the bloom period, the coastal waters were colored reddish, which was attributed to the bloom of Noctiluca. This is the first record of a red tide with this characteristic color on the northern coast of RS; all previous records refer to the southern coast of RS, bordering Uruguay (MACHADO, 1979; ROSA; BUSELATO, 1981, GARCIA et al., 1994, ODEBRECHT et al., 1995, MENDEZ, 1995).

Nauplii were abundant in the net sample. No dead animals were seen in the ocean during the three days of the bloom, or during seven days of observation of the sample in the laboratory. Unfortunately, the state Environmental Protection Agency does not monitor $\mathrm{HAB}$ along the coast, but only water quality along the beaches (by coliform bacteria counts). Although in this case the bloom was not harmful, another bloom of this species in the Gulf of Mannar (India) caused mortality of marine organisms and also formed a thick mucus-like layer that settled on the seaweeds, corals and the bottom sediment. This led to the death of almost all the local marine fauna and flora,_by asphyxiation (GOPAKUMAR et al., 2009). Because of the potential for harm, a HAB monitoring program must be implemented in RS, especially during summer when the beaches are crowded.

Microscopic examination of living Noctiluca cells showed a weakly twisted flagellum. The density of $N$. scintillans on day 2 of the bloom (December 18 2008) was $144 \times 10^{3}$ cells. $L^{-1}$; the population consisted of large-diameter cells $(600-1000 \mu \mathrm{m})$. The water temperature was $18{ }^{\circ} \mathrm{C}$, which is characteristic of the South Atlantic Central Water (SACW) according to Möller et al. (2008). The cell density of N. scintillans was similar to those reported by previous observers around the world (Table 1). Unfortunately neither nutrients nor chlorophyll $a$ were measured during this bloom.

Noctiluca scintillans is distributed globally in cold and warm waters (KIØRBOE, 2003). Under laboratory conditions, $N$. scintillans reproduced actively at low temperatures, showing similar growth rates in two experiments $\left(\mathrm{k}=0.2 \mathrm{day}^{-1}\right)$, close to the growth rates reported in the literature for higher temperatures (UMANI et al., 2004). In the case of $N$. scintillans, a temperature change is thought to be the dominant factor in triggering the onset of a bloom (UHLIG; SAHLING, 1990).

Table 1. Some blooms of Noctiluca around the world.

\begin{tabular}{|c|c|c|c|}
\hline Study sites & density (cells. $L^{-1}$ ) & Reference & Obs \\
\hline $\begin{array}{l}\text { Tramandai beach, Southern } \\
\text { Brazil }\end{array}$ & $144 \times 10^{3}$ & this study & \\
\hline $\begin{array}{l}\text { Dapeng Bay, the South China } \\
\text { Sea }\end{array}$ & surface $10^{4}$ to $10^{5}$ & $\begin{array}{l}\text { Huang \& Qi, 1997; Wang et al., } \\
2008\end{array}$ & summer and fall \\
\hline subsurface $10^{3}$ to $10^{4}$ & Huang \& Qi, 1997 & & \\
\hline Minnie Bay, Port Blair & 1.5 to $2.3 \times 10^{4}$ & Eashwar et al., 2001 & \\
\hline Minnie Bay, Port Blair & $17 \times 10^{3}$ & Dharani et al., 2004 & bloom $48 \mathrm{~h}$ \\
\hline Sagami Bay, Japan & Miyaguchi et al., 2006 & & \\
\hline Thailand & $18.7 \times 10^{3}$ & Sriwoon et al., 2008 & $\begin{array}{l}\text { maximum in June } 2003 \text { during } \\
\text { monsoon periods }\end{array}$ \\
\hline $\begin{array}{l}\text { Gulf of Mannar (southeast } \\
\text { coast of India) }\end{array}$ & $5.1 \times 10^{5}$ to $13.5 \times 10^{5}$ & Gopakumar et al., 2009 & $\begin{array}{l}\text { intense bloom } 2 \text { to } \\
13 / \text { October/2008 }\end{array}$ \\
\hline South-eastern Australia & 0.1 to $1 \times 10^{4}$ & Murray \& Suthers, 1999 & spring and late summer \\
\hline
\end{tabular}

[1]Photographs of the bloom are available at http://www.lei.furg.br/taxonomia/site/index.php and http://www.clicrbs.com.br/busca/rs?q=mare vermelha\&c $=004339507562457011598$ : slvytw1qlpm\&t=local 
The recent increased frequency of algal blooms worldwide has led some scientists to believe that a change in marine planktonic ecosystems on a global scale is being caused by human alterations to the coastal zone (DHARANI et al., 2004). It is well understood that the outbreak of an algal bloom is a result of a complex interplay among temperature, currents, wind and nutrients (GOPAKUMAR et al., 2009). A rich food supply is necessary for Noctiluca to reproduce massively, but a suitable temperature and stable humid weather without heavy rain are also considered to be important factors (HUANG; QI, 1997).

Several factors are proposed_as affecting the population dynamics of red Noctiluca in temperate waters, as summarized by Elbrachter and QI (1998); these factors include temperature, salinity, light, food supply, cellular buoyancy, and physical processes that determine the spatial distribution of the organism. Because of its heterotrophic nature, prey availability is essential for the growth of red Noctiluca (SRIWOON et al., 2008). Red Noctiluca is a voracious predator, with a diverse diet ranging from phytoplankton to copepods and fish eggs (HATTORI, 1962; KIMOR, 1979; SCHAUMANN et al., 1988; NAKAMURA, 1998). A suggested link between increasing bloom events of red Noctiluca and the eutrophication of coastal waters is enhanced prey availability due to eutrophication. Various factors other than food supply also play a role in the population dynamics of red Noctiluca, the relative importance of which probably changes according to the locality, phase of bloom formation, and environmental conditions (UHLIG; SAHLING, 1995; ELBRACHTER; QI, 1998). The present case is the first reported instance of a red Noctiluca bloom in RS, and the coastal waters in this region, as in other parts of the world, are becoming increasingly eutrophic. Without a $\mathrm{HAB}$ monitoring program, it is difficult to assess the specific cause of this red bloom. However, it is often very difficult to determine the specific cause of an algal bloom. In extensively studied areas such as Port Blair Bay, the origin of Noctiluca blooms is not always concurrent with nutrient inputs (EASHWAR et al., 2001), although it has been suggested that local enrichment of nutrients by terrigenous and allochthonous inputs to the coastal waters of Port Blair Bay may be one of the important causative factors (DHARANI et al., 2004).

Although the precise cause of the present bloom is unclear, we suggest that probably the short period of the bloom (three days) was a result of freshwater output from the Tramandaí Lagoon channel, because Noctiluca requires high salinity and is more often found in cool water (e.g., in neighboring Uruguay). In the net sample, nauplii were abundant, which contributed to the food supply and may have been one of the important causative factors of this red Noctiluca bloom.

\section{ACKNOWLEDGMENTS}

Many thanks to MSc. Maurício Tavares, biologist of CECLIMAR (Centro de Estudos Costeiros, Limnológicos e Marinhos), who sampled water from the bloom; to PETROBRAS, which provided the vessel; to the journalist Marcelo Gonzatto of the Zero Hora newspaper, for his accurate reporting of the scientific background of the bloom; and to Dr. Clarice Odebrecht of FURG (Fundação Universitária de Rio Grande) for all her comments about blooms in Rio Grande do Sul. Dr. Janet W. Reid (JWR Associates) edited the English text.

\section{REFERENCES}

AJANI, P.; HALLEGRAEFF, G.; PRITCHARD, T. Historic overview of algal blooms in marine and estuarine waters of New South Wales, Australia. Proc. Linn. Soc. New South Wales, v.. 123, p. 1-22, 2001

APHA. Standard methods for examination of water and wastewater. Washington D.C.: American Public Health Society Pub., 1995.

DELA-CRUZ, J.; AJANI, P.; LEE, R.; et al. Temporal abundance patterns of the red tide dinoflagellates Noctiluca scintillans along the southeast coast of Australia. Mar. Ecol. Prog. Ser., v. 236, p. 75-88, 2002.

DHARANI, G.; NAZAR, A. K. A.; KANAGU, L.; et al. On the recurrence of Noctiluca scintillans bloom in Minnie Bay, Port Blair: Impact on water quality and bioactivity of extracts. Curr. Sci., v. 87, n. 7, p. 990-994, 2004.

EASHWAR, M.; NALLATHAMBI, T.; KUBERARAJ, K.; et al. Noctiluca blooms in Port Blair Bay, Andamans. Curr. Sci., v. 81, n. 2, p. 203-205, 2001.

ELBRACHTER, M.; QI, Y. Z. Aspects of Noctiluca (Dinophycae) population dynamics. In: ANDERSON, D. M.; CAMBELLA, A. D.; HALLEGRAEFF, G. M. (Ed.). Physiological ecology of harmful algal blooms.London: Springer, 1998. p. 315-336.

ESCALERA, L.; PAZOS, Y.; MORONO, A.; et al. Noctiluca scintillans may act as a vector of toxigenic microalgae. Harmful Algae, v. 6, n. 3, p. 317-320, 2007.

GARCIA, V. M. T.; ODEBRECHT, C.; RÖRIG, L. R. Florações nocivas de fitoplâncton na costa brasileira. IOC Workshop Report, n. 101, p. 9-14, 1994.

GOPAKUMAR, G.; SULOCHANAN, B.; VENKATESAN, V. Bloom of Noctiluca scintillans (Macartney) in Gulf of Mannar, southeast coast of India. J. Mar. Biol. Ass. India, v. 51, n. 1, p. 75-80, 2009.

HATTORI, S. Predatory activity of Noctiluca on anchovy eggs. Bull. Tokai Reg. Fish. Res. Lab., v. 9, p. 211-20, 1962.

HUANG, C.; QI, Y. The abundance cycle and influence factors on red tide phenomena of Noctiluca scintillans (Dinophyceae) in Dapeng Bay, the South China Sea. J. Plankton Res., v. 19, n. 3, p. 303-318, 1997. 
KIØRBOE, T. High turnover rates of copepod fecal pellets due to Noctiluca scintillans grazing. Mar. Ecol. Prog. Ser., v. 258, p. 181-188, 2003

KIMOR, B. Predation by Noctiluca miliaris Suriray on Acartia tonsa Dana eggs in the inshore waters of southern California. Limnol. Oceanogr., v. 24, p. 568$72,1979$.

MACHADO, P. A. Dinoflagellate bloom on the Brazilian South Atlantic coast. In: TAYLOR, D.L.; SELIGER, H.H. (Ed.). Toxic Dinoflagellate Blooms. New York: Elsevier, 1979. p. 29-32

MÉNDEZ, S. Bivalve mortality on Southwest Atlantic shores. Harmful Algae News, n. 10/11, p. 12, 1995.

MIYAGUCI, H.; FUJIKI, T.; KIKUCI, T. et al. Relatioship between the bloom of Noctiluca scintillans and environmental factors in the coastal waters of Sagami Bay, Japan. J. Plankton Res., v. 28, n. 3, p. 313-324, 2006.

MOHAMED, Z. A.; MESAAD, I. First report on Noctiluca scintillans blooms in the Red Sea off the coasts of Saudi Arabia: consequences of eutrophication. Oceanologia, v. 49, n. 3, p. 337-351, 2007

MÖLLER, O. O.; PIOLA, A. R.; FREITAS, A. C.; et al. The effects of river discharge and seasonal winds on the shelf off southeastern South America. Cont. Shelf Res. p. 1607-1624, 2008.

MURRAY, S.; SUTHERS, I. M. Population ecology of Noctiluca scintillans Macartney, a red-tide-forming dinoflagellate. Mar. Fresh. Res., v. 50, n. 3, p. 243-252, 1999.

NAKAMURA, Y. Biomass, feeding and production of Noctiluca scintillans in the Seto Inland Sea, Japan. J. Plankton Res., v. 20, p. 2213-2222, 1998.

ODEBRECHT, C.; RÖRIG, L.; GARCIA, V. M. T.; et al. Shellfish mortality and a red tide event in southern Brazil. In: LASSUS, P.; ARZUL, G.; ERARD, E.; et al. (Ed.). Harmful Marine Algal Blooms. Lavousier: Intercept Ltd, 1995. p. 213-218.
ROSA, Z. J.; BUSELATO, T. C. Sobre a ocorrência de floração de Gyrodinium aureolum Hulburt (Dinophyceae) no litoral do Estado do Rio Grande do Sul, Brasil. Iheringia, v. 28, p. 169-179, 1981.

SAITO, H.; FURUYA, K. Endosymbiosis in microalgae with special attention to Noctiluca scintillans. Bull. Plankton Soc. Jpn., v. 53, p. 14-21, 2006.

SCHAUMANN, K.; GERDES, D.; HESSE, K. J. Hydrographic and biological characteristics of a Noctiluca scintillans red tide in the German Bight, 1984. Meeresforschung, v. 32, p. 77-91, 1988.

SRIWOON, R.; PHOLPUNTHIN, $\quad$ P.; LIRDWITAYAPRASIT, T. Population dynamics of green Noctiluca scintillans (dinophyceae) associated with the monsoon cycle in the upper gulf of Thailand. J. Phycol., v. 44, p. 605-615, 2008.

UHLIG, G.; SAHLING, G. Long-term studies on Noctiluca scintillans in the German Bight. Population dynamics and red tide phenomena 1968-1988. Neth. J. Sea Res., v. 25, p. 101-112, 1990.

UHLIG, G.; SAHLING, G. Noctiluca scintillans: Zeitliche Verteilung bei Helgoland und räumliche Verbreitung in der Deutschen Bucht (Langzeitreihen 1970-1993). Ber. Biol. Anst. Helgoland, v. 9, p. 1-127, 1995.

UMANI, S. F.; BERAN, A.; PARLATO, S.; et al. Noctiluca scintillans Macartney in the Northern Adriatic Sea: longterm dynamics, relationships with temperature and eutrophication, and role in the food web. J. Plankton Res., v. 26, n. 5, p. 545-561, 2004.

WANG, S. F.; TANG, D. L.; HE, F. L.; et al. Occurrences of harmful algal blooms (HABs) associated with ocean environments in the South China Sea.Hydrobiologia, v. 596 , p. 79-93, 2008

(Manuscript received 25 May 2011; revised 09 December 2011; accepted 05 March 2012) 